\section{1. 〈も膜下出血と低体温療法}

\section{京都大学医学部脳神経外科}

野崎 和彦

近年，頭部外傷モデルや脳虚血モデルにおいて低温による 脳保護作用が示され，重症頭部外傷や虚血性疾患への臨床応 用が進められ，その有効性を示す報告が散見される。一方， 脳動脈瘤破裂によるくも膜下出血における低体温療法の適 応・有効性山明らかにされていない。脳動脈瘤治療における 低体温療法導入の可能性として，1）体外循環下 profound hypothermia のもとでの巨大脳動脈瘤または深部脳動脈瘤 根治術，2）脳動脈瘤破裂による重症くも膜下出血における 脳保護を目的とした mild hypothermia，3）くも膜下出血後 の難治性脳血管攣縮に対する mild hypothermia が上げられ る。当施設・関連病院に扔いて経験したくも膜下出血患者の 低体温療法適応症例の臨床成績，および現在までの他施設よ りの報告例を検討し，〈も膜下出血における低体温療法の適 応，問題点につき概説する。

\section{3. 心原性脸塞栓症急性期における低体温治療}

国立循環器病センター内科脳血管部門 成冨 博章, 長束 一行, 宮下光太郎 森脇 博, 渡辺 吉将, 山脇 健盛

虚血性脳障害の程度は体温上昇または下降により大きく左 右されることが実験的に知られている。脳梗塞急性期に体温 上昇を示す例は少なくなく，我々の検討では心原性脳塞栓症 例, 特に虚血範囲の広い例において, 体温上昇頻度が高い傾 向が認められた。発症早期に体温上昇を示した例はその後出 血性変化や高度脳浮腫を示す頻度が高いことから，脳塞栓症 例における体温上下は予後と密接に結びつく可能性が強い. そこで我々は塞栓性の主幹動脈閉塞例に対し, 主として超急 性期（発症 6 時間以内）に軽微低体温治療（脳温 $33^{\circ} \mathrm{C}, 3-7$ 日間）を行い，その有効性を検討中である．未だ例数は少な いが，低体温治療は特に脳浮腫抑制効果の点で優れていると 思われる．現在まで大半の例では血栓溶解治療を併用してき たが，再開通が認められなかった例においても転帰は比較的 良好であった。そこで今後, 低体温単独治療の有効性も追求 していく必要があると考えている。

\section{4. 重症頭部外傷症例に対する低体温療法の意義 久留米大学医学部脳神経外科 徳富 孝志, 森本一弥, 石川 和史 重森稔}

重症脳損傷急性期の管理法の向上や各種モニタリングの普 及にもかかわらず，重症頭部外傷特に GCS 5 以下の最重症 例の転帰はいまだに極めて不良である。一方，軽度低体温の 脳保護作用が実験的に立証されて以来，軽度低体温療法は臨 床的にも応用されつつある.我々の施設でも1994 年以降 GCS 5 以下の重症頭部外傷症例に対して $32 \sim 33^{\circ} \mathrm{C}$ を目標と した低体温療法を行ってきた。その結果，本療法により頭蓋 内圧のコントロールが容易となること，また外傷後の代謝・ 異化光進を抑制し同時に循環抑制もきたすが両者はcouplingして変動するため急性期虚血状態には保護的に作用す るであろうことを明らかにした。しかしながら低体温療法導 入以前の転帰と比較しても有意差は認められていない。その 原因としては，低体温の脳保護効果の限界，あるいは低体温 による生体防御機構の抑制に伴う副作用の影響などが示唆さ れる。以上の結果や問題点につき自験例をもとに報告する。 